\title{
The Effect of Season on Somatic Cell Count and the Incidence of Clinical Mastitis
}

\author{
R. G. M. Olde Riekerink, ${ }^{\star 1}$ H. W. Barkema, $†$ and H. Stryhn* \\ *Department of Health Management, University of Prince Edward Island, Charlottetown, Canada C1A 4P3 \\ †Faculty of Veterinary Medicine, University of Calgary, Calgary, Canada
}

\begin{abstract}
Bulk milk somatic cell count (BMSCC), individual cow somatic cell count (ICSCC), and incidence rate of clinical mastitis (IRCM) are all udder health parameters. So far, no studies have been reported on the effect of season on BMSCC, IRCM, and ICSCC in the same herds and period over multiple years. The objectives of this study were to determine the seasonal pattern over a 4-yr period of 1) BMSCC, 2) elevated ICSCC, 3) IRCM, and 4) pathogen-specific IRCM. Bulk milk somatic cell count, ICSCC, and pathogen-specific clinical mastitis data were recorded in 300 Dutch dairy farms. For the analyses of BMSCC, ICSCC, and IRCM, a mixed, a transitional, and a discrete time survival analysis model were used, respectively. Sine and cosine were included in the models to investigate seasonal patterns in the data. For all parameters, a seasonal effect was present. Bulk milk somatic cell count peaked in August to September in all 4 years. The probability of cows getting or maintaining a high ICSCC was highest in August and May, respectively. Older and late-lactation cows were more likely to develop or maintain a high ICSCC. Incidence rate of clinical mastitis was highest in December to January, except for Streptococcus uberis IRCM, which was highest in August. Totally confined herds had a higher Escherichia coli IRCM in summer than in winter. Compared with the major mastitis pathogens, the seasonal differences in IRCM were smaller for the minor pathogens. Distinguishing between Strep. uberis, Streptococcus dysgalactiae, Streptococcus agalactiae, and other streptococci is essential when identifying Streptococcus spp. because each of them has a unique epidemiology. Streptococcus uberis IRCM seemed to be associated with being on pasture, whereas $E$. coli IRCM was more housing-related.
\end{abstract}

Key words: somatic cell count, mastitis, incidence, season

Received September 1, 2006.

Accepted November 13, 2006.

${ }^{1}$ Corresponding author: rolderiek@upei.ca

\section{INTRODUCTION}

Environmental and climatologic factors affect the incidence of many diseases and disorders in dairy cows, such as mastitis (Morse et al., 1988; Whitaker et al., 2004). Therefore, incidence of these diseases often has a seasonal pattern. This seasonal pattern, however, can also be the result of a season-specific average stage of lactation of the herd, especially in herds where the calving pattern of dairy cows tends to be seasonal.

Bulk milk SCC (BMSCC) in a herd is mainly influenced by the prevalence and incidence of subclinical and clinical mastitis, which depends on factors such as parity, stage of lactation, type of housing, access to pasture, management, and environmental factors; for example, temperature, humidity, and season (Simensen, 1976; Morse et al., 1988; Hogan and Smith, 1997; Faye et al., 1998). In herds with year-round calving, SCC had a seasonal pattern, with the highest BMSCC occurring from July to October (Schukken et al., 1993; Sargeant et al., 1998a). Seasonal patterns can also be found in individual cow SCC (ICSCC), with generally the highest ICSCC in July and August (Bodoh et al., 1976; Salsberg et al., 1984). Green et al. (2006) suggested that part of the seasonal variation of BMSCC was caused by the larger proportion of cows with prolonged high ICSCC in the summer. Herds with a seasonal calving pattern in the southern hemisphere; for example, in New Zealand, had the highest BMSCC around the calving period in the winter months (July to September). The lowest BMSCC in these herds occurred in September to October, shortly after the calving period, and BMSCC then slowly increased again toward the end of the season in April to May (Clements et al., 2005).

Seasonal effects have also been reported for the incidence rate of clinical mastitis (IRCM), with the highest IRCM for streptococci and coliforms in the summer months of June to August in confined US dairy herds (Erskine et al., 1988; Hogan et al., 1989a; Makovec and Ruegg, 2003). Because the epidemiology of each pathogen is unique, the effect on BMSCC and IRCM and its relationship to climatic and environmental fac- 
tors might be different. Summer humidity and temperature increase coliform counts in bedding material, resulting in an increased coliform IRCM (Smith et al., 1985; Erskine et al., 1988).

Bulk milk SCC, ICSCC, and IRCM are all udder health parameters. Although studies have been conducted to determine the influence of season on BMSCC (Schukken et al., 1992), IRCM (Morse et al., 1988; Hogan et al., 1989a), and subclinical mastitis (Green et al., 2006), so far no studies have been reported on the effect of season on BMSCC, IRCM, and ICSCC in the same herds and period over multiple years. Additionally, the epidemiology of mastitis differs among the pathogens involved, and when studying the effect of season on the IRCM, ideally pathogen-specific IRCM should be studied. Therefore, the objectives of this study were to determine in the same herds the seasonal pattern over a 4-yr period of 1) BMSCC, 2) elevated ICSCC, 3) IRCM, and 4) pathogen-specific IRCM.

\section{MATERIALS AND METHODS}

\section{Herds and Sampling}

The data used in the present study were described in detail elsewhere (Barkema et al., 1998). In short, based on mean annual BMSCC, 3 categories were defined: $<150,000,151,000$ to 250,000 , and 251,000 to 400,000 cells $/ \mathrm{mL}$. For each category, 100 dairy herds were selected with at least 10 out of 13 preceding measurements and the last 3 of these within that BMSCC category. Furthermore, only herds that housed cows in freestall barns during winter, participated in a milkrecording program, had an annual quota between 300,000 and $900,000 \mathrm{~kg}$, and had cows of the HolsteinFriesian or Dutch Friesian breed were selected. The Dutch national milk recording system (Nederlands Rundvee Syndicaat, Arnhem, the Netherlands) provided information from milk recordings and BMSCC data. Farmers that participated in the study were asked to collect milk samples from cows with signs of clinical mastitis before treatment during the study period and record severity of signs, treatment, and affected quarter. Samples were stored in a freezer on the farm (at approximately $-20^{\circ} \mathrm{C}$ ) and collected every 6 to $8 \mathrm{wk}$ for bacteriological culture. Management data about use of pasture or confinement in the summer were derived from a questionnaire conducted on-farm and described elsewhere (Barkema et al., 1999b).

\section{Data}

For the analyses of the seasonality of the BMSCC, 11,292 monthly BMSCC measurements on 300 farms from January 5, 1992, to December 5, 1995, were used.
Every record contained herd identification, BMSCC, and the sampling date.

For the analyses of the ICSCC data, test-day recordings of 268 dairy farms between January 1, 1992, and December 31, 1995, were used. In total, 32 herds were excluded from this analysis because the farmers indicated that they sampled fewer than $75 \%$ of the clinical cases (18 herds), ceased farming activities ( 8 herds), or did not have regular ICSCC recordings with intervals of less than 6 wk (6 herds). Each test-day record contained information about herd identification, cow identification, parity, calving date, test-day date, kilograms of milk fat, protein, and milk production, and ICSCC. Records with test days less than $4 \mathrm{~d}$ after calving and records with more than $500 \mathrm{~d}$ after calving were removed. Records were removed if the test date of that record was more than 35 or less than $21 \mathrm{~d}$ apart from the preceding test day.

The data set for IRCM analysis contained 274 farms with each record representing 1 lactation that was full or partial within the study period of that farm. A partial lactation started before and ended within the study period or started within and ended after the study period. Only herds in which the farmers indicated that fewer than $75 \%$ of clinical cases were sampled and herds that ceased farming activities were excluded from this analysis. Each farm participated in the study for approximately 18 mo between January 1, 1992, and December 31, 1995. Data consisted of herd identification, cow identification, parity, calving date, expected calving date, cull date, dry-off date, on-farm arrival date, date the herd entered the study, date the herd exited the study, and dates and culture results of up to 3 clinical mastitis cases per lactation. Records with biologically impossible combinations of dates were removed, leaving 49,777 full or partial lactations of 29,258 cows for the analyses. At least one recorded case of clinical mastitis occurred in 6,168 lactations. Distribution of pathogens isolated from milk samples from clinical cases was described elsewhere (Barkema et al., 1998). In short, the major pathogens Escherichia coli, Staphylococcus aureus, Streptococcus dysgalactiae, and Strep. uberis were isolated 1,501 (21.3\% of all cases), 1,666 (23.7\%), $946(13.4 \%)$, and $513(7.3 \%)$ times, respectively; the minor pathogens CNS and Corynebacterium bovis were isolated $456(6.5 \%)$ and $420(6.0 \%)$ times, respectively, and samples that were culture-negative occurred 1,083 $(15.4 \%)$ times.

\section{Statistical Analyses}

Seasonality of BMSCC of all 300 herds that started in the study was assessed using a mixed model with herd random effects and autocorrelated errors for the 
repeated measures on herds (PROC MIXED; SAS software version 8.2; SAS Institute, Inc., Cary, NC). To approximate the normal distribution, a natural logarithmic transformation of the BMSCC divided by 1,000 cells/mL was used, which is the optimum transformation for SCC in milk (Ali and Shook, 1980). Sine and cosine terms with a yearly period were included in the model to estimate the seasonal effect (Stolwijk et al., 1999). To correct for year effects, separate parameters were estimated for each year. The model in year $\mathrm{k}$ for the jth measurement at herd i was as follows:

$$
\begin{gathered}
\ln \left(\text { BMSCC }_{)_{\mathrm{jjk}}}=\beta_{0 \mathrm{k}}+\beta_{1 \mathrm{k}} \sin \left(2 \pi \times \mathrm{day}_{\mathrm{ijk}} / 365.25\right)\right. \\
+\beta_{2 \mathrm{k}} \cos \left(2 \pi \times \operatorname{day}_{\mathrm{ijk}} / 365.25\right)+\mathrm{u}_{\mathrm{i}}+\varepsilon_{\mathrm{ijk}}
\end{gathered}
$$

where $\ln (\mathrm{BMSCC})=$ natural log of BMSCC; $\beta_{0 \mathrm{k}}=$ intercept in year $\mathrm{k} ; \beta_{1 \mathrm{k},}, \beta_{2 \mathrm{k}}=$ regression coefficients in year $\mathrm{k} ; \mathrm{u}_{\mathrm{i}}=$ random effect for herd $\mathrm{i}$; and $\varepsilon_{\mathrm{ijk}}=$ residual error. The within-herd autocorrelation was modeled by a power function with an additional nugget effect (Littell et al., 1996).

Incidence rate of subclinical mastitis was assessed using a 4-level hierarchical transitional model while including random effects of herds, cows, and lactations. An ICSCC $\geq 200,000$ cells/mL was considered high, and an ICSCC $<200,000$ cells $/ \mathrm{mL}$ was considered low. Two consecutive ICSCC test days were classified in 4 categories: "low" (2 consecutive low ICSCC test days); "new" (a low ICSCC followed by a high ICSCC); "chronic" (2 consecutive high ICSCC); and "cure" (high ICSCC followed by a low ICSCC), as detailed in Schukken et al. (2003). Parity was evaluated against the proportion of high ICSCC and was categorized in 4 categories: heifers; second and third parity; fourth and fifth parity; and sixth and later parities. The model for the probability of high ICSCC at test-day 1 within the kth lactation of cow $\mathrm{j}$ in herd $\mathrm{i}$ was as follows:

$$
\begin{aligned}
& \operatorname{logit}\left(\mathrm{p}_{\mathrm{ijk} \mathrm{l}}\right)=\beta_{0}+\beta_{1} \text { prev_hiscc }_{\mathrm{ijkl}}+\beta_{2} \text { prev_hiscc }{ }_{\mathrm{ijkl}} \\
& \times \sin \left(2 \pi \times \text { day }_{\mathrm{ijkl}} / 365.25\right)+\beta_{3} \text { prev_hiscc } \mathrm{ijkl} \\
& \times \cos \left(2 \pi \times \text { day }_{\mathrm{ijkl}} / 365.25\right)+\beta_{4}\left(1-\text { prev_hiscc }_{\mathrm{ijkl}}\right) \\
& \times \sin \left(2 \pi \times \text { day }_{\mathrm{ijkl}} / 365.25\right)+\beta_{5}\left(1-\text { prev_hiscc }_{\mathrm{ijkl}}\right) \\
& \times \cos \left(2 \pi \times \text { day }_{\mathrm{ijk}} / 365.25\right)+\beta_{6} \operatorname{dim}_{\mathrm{ijkl}} \\
& +\beta_{7} \text { parity_cat } 23_{\mathrm{ijk}}+\beta_{8} \text { parity_cat } 45_{\mathrm{ijk}} \\
& +\beta_{9} \text { parity_cat } 6_{\mathrm{ijk}}+\beta_{10}(\text { parity_cat } 23 \times \text { prev_hiscc })_{\mathrm{ijkl}} \\
& \left.+\beta_{11} \text { (parity_cat45 } \times \text { prev_hiscc }\right)_{\mathrm{ijkl}} \\
& \left.+\beta_{12} \text { (parity_cat6 } \times \text { prev_hiscc) }\right)_{\mathrm{ijkl}}+\beta_{13} \text { yr1992 } 2_{\mathrm{ijkl}}
\end{aligned}
$$

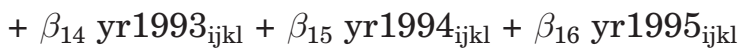

$$
\begin{aligned}
& +\mathrm{u}_{\mathrm{i}}+\mathrm{v}_{\mathrm{ij}}+\mathrm{w}_{\mathrm{ijk}}
\end{aligned}
$$

Journal of Dairy Science Vol. 90 No. 4, 2007 where $\mathrm{p}_{\mathrm{ijkl}}=$ probability of a high ICSCC; $\beta_{1}=$ the coefficient for the previous test day (prev_hiscc) being a high ICSCC; $\beta_{2}$ and $\beta_{3}=$ the coefficients for the sine and cosine in case the previous ICSCC was high; $\beta_{4}$ and $\beta_{5}=$ the coefficients for the sine and cosine in case the previous ICSCC was low; $\beta_{6}=$ the coefficient for lactation stage or DIM; $\beta_{7}$ to $\beta_{9}=$ coefficients for parity; $\beta_{10}$ to $\beta_{12}=$ coefficients for the interaction of parity and previous high ICSCC; $\beta_{13}$ to $\beta_{16}=$ coefficients for years (1992 to 1995); and $\mathrm{u}_{\mathrm{i}}, \mathrm{v}_{\mathrm{ij}}$ and $\mathrm{w}_{\mathrm{ijk}}=$ the random effects for herd $\mathrm{i}$, cow $\mathrm{j}$, and lactation $\mathrm{k}$, respectively, where $\mathrm{i}=$ herd, $\mathrm{j}=$ cow within herd, $\mathrm{k}=$ lactation within cow, and $\mathrm{l}=$ test day within lactation. First-order marginal quasi-likelihood estimates of coefficients were derived using the restricted generalized iterative least squares algorithm in MLwiN (Rasbash et al., 2000). Intraclass correlation coefficients were estimated using the latent variable approximation (Vigre et al., 2004).

Seasonal effects on IRCM were estimated for either all cases or pathogen-specific cases using a multilevel discrete time survival analysis with herd and cow random effects (Singer and Willett, 1993, 2003). To be able to use calendar time as a predictor in the analysis, biological time, or DIM, was used as the survival time. Days in milk were categorized in periods of $14 \mathrm{~d}$. Lactation periods after 420 DIM (30 periods of $14 \mathrm{~d}$ ) were omitted because pathogen-specific IRCM after that time was low or zero per period. A second or third case of clinical mastitis in the same lactation, regardless of culture result, was considered a new case if there were at least $14 \mathrm{~d}$ between the previous and the current case of clinical mastitis. The first consecutive 14 -d period at risk in a lactation that started at least $14 \mathrm{~d}$ after a case of clinical mastitis was included in the analysis again. Left truncated lactations were considered at risk from the first complete 14-d period starting after the day the herd entered the study. Lactations were right censored after the last full 14-d period before the end of the study period. Variables for year were included in the model; however, herds participated in the study for no longer than $1.5 \mathrm{yr}$. Therefore, the random effect of herds will account for a large part of the year effect. Year effect did not change the coefficients of interest substantially. For simplicity, the variable for year effect was omitted from the model. For all clinical mastitis cases and for all pathogen-specific cases, a 3-category variable containing summer housing data (outside day and night, inside at night, and inside day and night) was included in the model, including its interactions with the season variables. These variables were removed if they were not significant. The basic model for the hazard of a "failure" (clinical mastitis) in period $\mathrm{k}$ of cow $\mathrm{j}$ in herd i was as follows: 


$$
\begin{gathered}
\operatorname{logit}\left(\mathrm{p}_{\mathrm{ijk}}\right)=\alpha_{\mathrm{k}}+\beta_{1} \sin \left(2 \pi \times \text { day }_{\mathrm{ijk}} / 365.25\right) \\
+\beta_{2} \cos \left(2 \pi \times \text { day }_{\mathrm{ijk}} / 365.25\right)+\beta_{3}{\text { parity_cat } 23_{\mathrm{ij}}} \\
+\beta_{4} \text { parity_cat45 } 5_{\mathrm{ij}}+\beta_{5} \text { parity_cat6 }_{\mathrm{ij}} \\
+\beta_{6} \text { night_in }_{\mathrm{i}}+\beta_{7} \text { confined }_{\mathrm{i}}+\mathrm{u}_{\mathrm{i}}+\mathrm{v}_{\mathrm{ij}}
\end{gathered}
$$

where $\mathrm{p}_{\mathrm{ijk}}$ is the hazard of a "failure" (clinical mastitis), and on logistic scale, $\alpha_{\mathrm{k}}$ is the baseline hazard for the kth 14-d period in the lactation; $\beta_{1}$ and $\beta_{2}=$ the coefficients for the sine and cosine terms; $\beta_{3}=$ the coefficient for second and third parities (parity_cat23); $\beta_{4}=$ the coefficient for fourth and fifth parities (parity_cat45); $\beta_{5}=$ the coefficient for sixth and later parities (parity_cat6); $\beta_{6}=$ the coefficient for herds that keep their cows inside at night (night_in); $\beta_{7}=$ the coefficient for totally confined herds; and $\mathrm{u}_{\mathrm{i}}$ and $\mathrm{v}_{\mathrm{ij}}$ the random effects for herd $i$ and cow $j$ (within herd $i$ ), respectively. First-order marginal quasi-likelihood estimates of coefficients were derived using the restricted generalized iterative least-squares algorithm in MLwiN (Rasbash et al., 2000). Intraclass correlation coefficients were estimated using the latent variable approximation (Vigre et al., 2004). The above model [3] was also used for pathogen-specific IRCM, where $p_{i j k}$ is the hazard of a case of clinical mastitis caused by a specific pathogen. Amplitude $\alpha$ and phase shift $\varphi$ of the predicted sine waves in equations [1], [2], and [3] were calculated using formulas that were described earlier (Stolwijk et al., 1999). Standard errors of the amplitude and phase shift were approximated using the "delta method" (Weisberg, 2005). Formulas are available from the authors on request. Winter, spring, summer, and autumn were defined as the period in a year from December 21 to March 20, March 21 to June 20, June 21 to September 20, and September 21 to December 20, respectively.

\section{RESULTS}

The number of cows that calved per week changed over the year, both for heifers and for multiparous cows. More cows and heifers calved in autumn and fewer calved in summer (Figure 1). This difference was larger for heifers than for cows. Of 9,293 heifers that calved during the study period, 324 calved in June compared with 1,169 in September, and out of 22,620 multiparous cows that calved during the study period, 1,663 calved in June compared with 2,057 in September (Figure 1).

\section{Bulk Milk SCC}

Bulk milk SCC of the 300 farms ranged from 28,000 to 740,000 cells/mL with a geometric mean of 187,000 cells/mL across all farms over the study period.

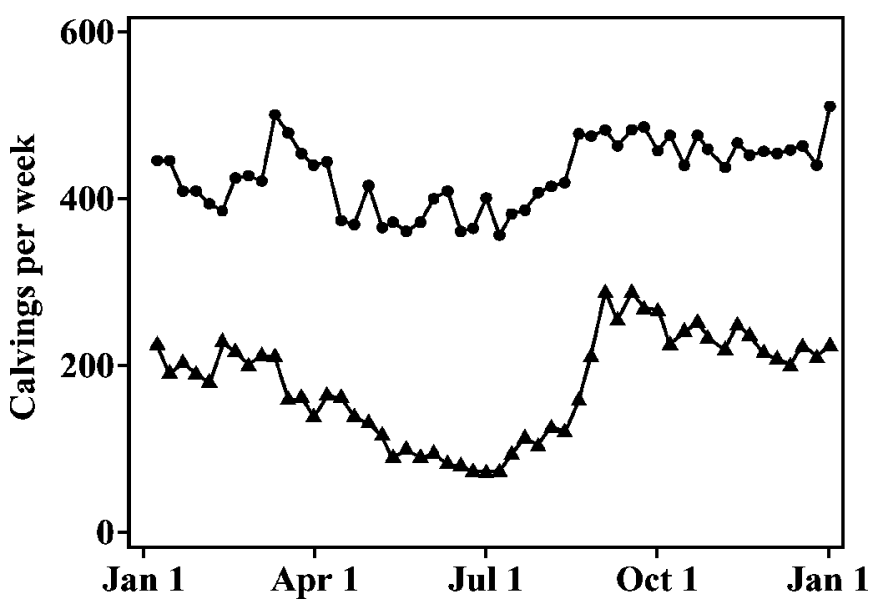

Figure 1. Average weekly number of calvings during the study period for heifers (A) and multiparous cows (O) in 300 Dutch dairy herds.

Season had a significant effect on geometric mean BMSCC per day of the study period in all 4 yr (Figure 2 ; Table 1). The amplitude of the seasonal effect differed among the 4 yr included in the study and was largest in 1995 (Table 1). Modeled BMSCC was highest at 209,000 cells/mL in September 1995 and lowest at 150,000 cells/ $\mathrm{mL}$ in March 1995. The seasonal variation of geometric mean BMSCC within a year ranged between 26,000 cells/mL in 1993 and 59,000 cells/mL in 1995. There were no differences in geometric mean BMSCC between the 3 categories of summer housing: outside day and night, inside at night, and inside day and night $(P>0.5)$.

\section{High ICSCC}

Data structure of ICSCC records that were used in the transitional model consisted of 4 levels: herd (268),

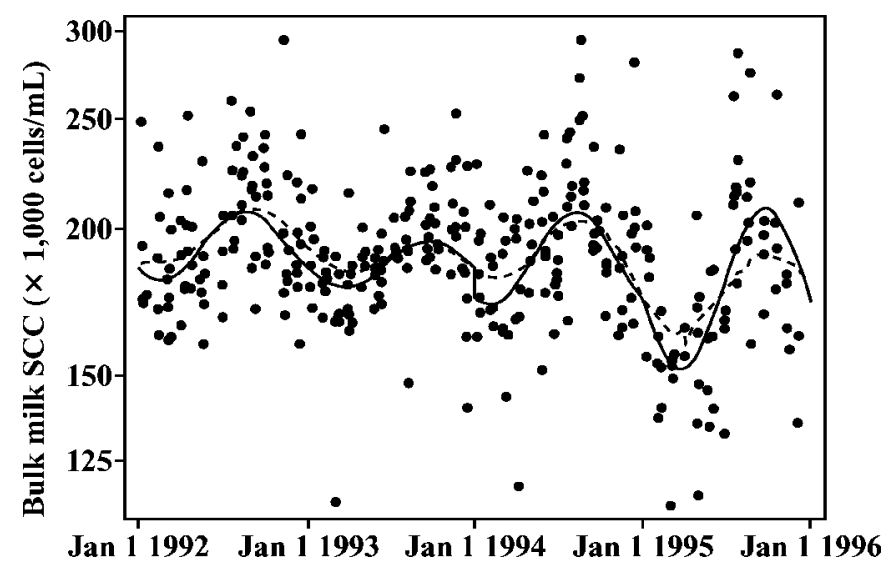

Figure 2. Geometric mean weekly bulk milk SCC of 300 Dutch dairy herds from January 1992 to January 1996; lowess smoother (dashed line, bandwidth 0.2) and model prediction (solid line). 
Table 1. Final model of seasonal variation of the natural log of bulk milk SCC (1,000 cells $/ \mathrm{mL})$ of 300 Dutch dairy herds

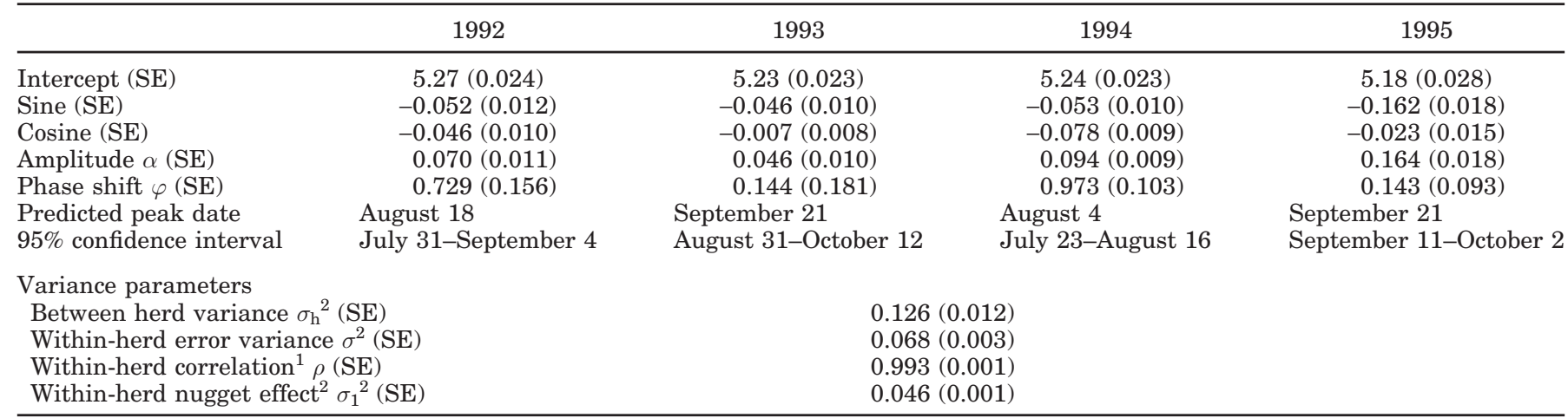

${ }^{1}$ Between outcomes at 2 test days $d$ days apart, the correlation is $\left(\sigma_{\mathrm{h}}{ }^{2}+\sigma^{2} \rho^{\mathrm{d}}\right) /\left({\sigma_{\mathrm{h}}}^{2}+\sigma^{2}+\sigma_{1}{ }^{2}\right)$.

${ }^{2}$ See Littell et al. (1996).

cow within herd (31,007), lactation within cow $(59,200)$, and test day within lactation $(409,932)$. Of 409,932 testday recordings in the final data set for ICSCC, $23.8 \%$ were greater than 200,000 cells/mL: heifers had $11.8 \%$ high ICSCC test-day recordings out of 127,968 , and $29.3 \%$ of the records of the multiparous cows had a high ICSCC. In the transitional model, predictors for season were significant, meaning that both patterns of "new" high ICSCC and "chronic" high ICSCC were seasonal (Table 2; Figures 3 and 4). Because the 12-mo sine wave in the model can only show 1 peak, it puts the peak of "new" cases of high ICSCC in the summer on August 7 (95\% confidence interval: July 26 to August 19), and therefore the dip in February. Although accounted for, the model could not show a second, shorter lasting peak in "new" high ICSCC for both heifers and multiparous cows in May (Table 2, Figure 3). "Chronic" high ICSCC cases more often occurred in spring with a predicted peak on April 28 (95\% confidence interval: April 13 to May 12), which is caused by a larger proportion of "chronic" high ICSCC in May to September in heifers and a peak in April and May in multiparous cows (Table 2 ; Figure 4). Older cows more often developed and maintained high ICSCC than younger cows (Table 2; Figures 3 and 4). Cows that were further in lactation more often had a high ICSCC than cows early in lactation (Table 2). Proportions of variance explained at herd, cow, lactation, and test-day level were $2.9,12.9,1.0$, and $83.2 \%$, respectively (Table 2 ).

\section{Incidence Rate of Clinical Mastitis}

In total, 7,083 cases of clinical mastitis were analyzed in the final data set. Data structure consisted of 3 levels: herd (274), cow within herd $(29,258)$, and lactation within cow $(49,777)$. The proportion of variance explained at the cow level was larger for pathogen-specific cases of clinical mastitis than for all cases of clinical mastitis, the largest being for Strep. uberis IRCM, closely followed by $C$. bovis IRCM (Table 3). Proportion of variance that was explained at the herd-level was

Table 2. Final model for the odds of ICSCC $\geq 200,000$ cells/mL ("high" ICSCC) on the logit scale

\begin{tabular}{|c|c|c|}
\hline Variable & Variance (SE) & $\%$ Variance \\
\hline \multicolumn{3}{|l|}{ Random effects } \\
\hline Herd & $0.113(0.011)$ & 2.9 \\
\hline Cow & $0.511(0.011)$ & 12.9 \\
\hline Lactation & $0.038(0.009)$ & 1.0 \\
\hline \multirow[t]{2}{*}{ Test day ${ }^{1}$} & - & 83.2 \\
\hline & $\beta(\mathrm{SE})$ & $P$ \\
\hline \multicolumn{3}{|l|}{ Fixed effects } \\
\hline Intercept & $-3.421(0.035)$ & $<0.001$ \\
\hline Previous high ICSCC & $2.254(0.024)$ & $<0.001$ \\
\hline Parity & & $<0.001$ \\
\hline Heifers & 0 (Reference) & \\
\hline Second to third parity & $0.761(0.016)$ & \\
\hline Fourth to fifth parity & $1.301(0.020)$ & \\
\hline$\geq$ Sixth parity & $1.663(0.025)$ & \\
\hline Parity $\times$ previous high ICSCC & & $<0.001$ \\
\hline Heifers & 0 (Reference) & \\
\hline Second to third parity & $-0.120(0.028)$ & \\
\hline Fourth to fifth parity & $-0.175(0.031)$ & \\
\hline$\geq$ Sixth parity & $-0.121(0.036)$ & \\
\hline DIM $(\times 100)$ & $-0.369(0.005)$ & $<0.001$ \\
\hline Season "new" high ICSCC ${ }^{2}$ & & $<0.001$ \\
\hline Sine & $-0.046(0.008)$ & \\
\hline Cosine & $-0.061(0.008)$ & \\
\hline Season "chronic" high ICSCC ${ }^{3}$ & & $<0.001$ \\
\hline Sine & $0.077(0.011)$ & \\
\hline Cosine & $-0.039(0.011)$ & \\
\hline Year & & $<0.001$ \\
\hline 1992 & 0 (Reference) & \\
\hline 1993 & $0.060(0.025)$ & \\
\hline 1994 & $0.061(0.025)$ & \\
\hline 1995 & $-0.076(0.026)$ & \\
\hline
\end{tabular}

${ }^{1}$ Assumes level 1 variance on the logit scale is $\pi^{2} / 3$, where $\pi=$ 3.1416... (Vigre et al., 2004).

"New" high ICSCC $=$ previous low $(<200,000$ cells $/ \mathrm{mL})$, current high ICSCC.

3"Chronic" high ICSCC = previous high and current high ICSCC. 


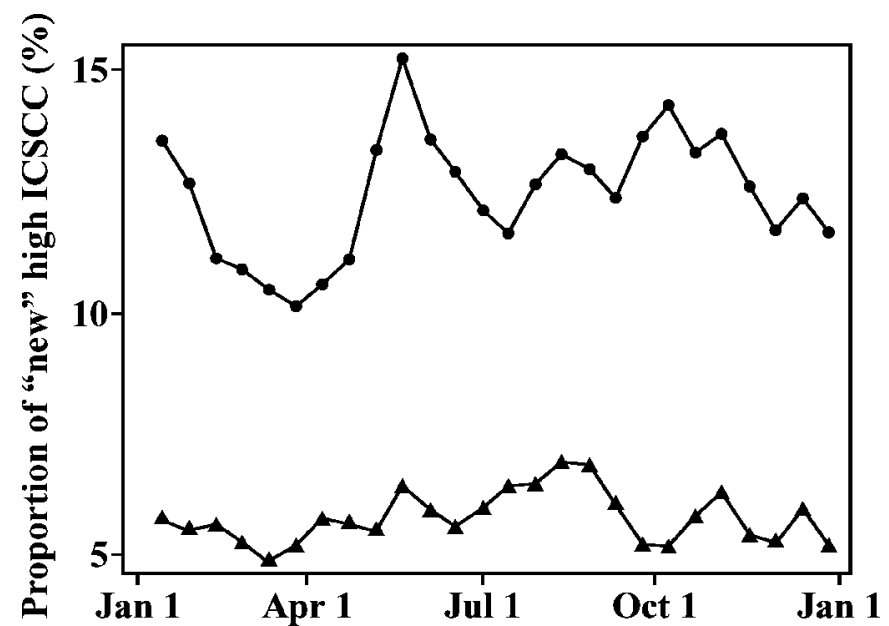

Figure 3. Proportion of "new" high individual cow SCC (ICSCC, $\geq 200,000$ cells $/ \mathrm{mL}$ ) per 14-d period for heifers (A) or multiparous cows (-) that had low ICSCC at the previous test day.

largest for culture-negative IRCM followed by Staph. aureus IRCM. Proportion of variance at herd-level was the largest for culture-negative clinical mastitis, followed at some distance by Staph. aureus and E. coli IRCM, respectively (Table 3 ).

The IRCM was highest in the first 14-d period after calving, declined steeply in the second period, and then, after a rise for multiparous cows only, declined more slowly over the rest of the lactation (Figure 5). This second peak was most pronounced for Staph. aureus and $E$. coli IRCM, whereas no second lactational peak could be found for Strep. uberis IRCM (Figure 6). In

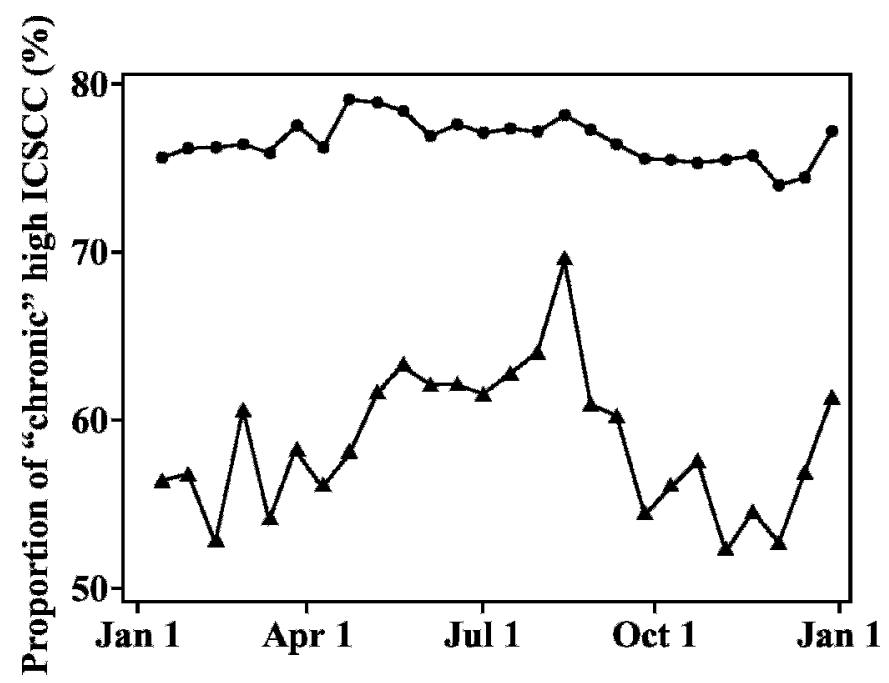

Figure 4. Proportion of "chronic" high individual cow SCC (ICSCC, $\geq 200,000$ cells $/ \mathrm{mL}$ ) per 14-d period for heifers (A) or multiparous cows (-) that had high ICSCC at the previous test day. addition, compared with heifers, multiparous cows were more likely to get clinical mastitis and had a higher IRCM over the whole lactation for all pathogens (Table 3). The IRCM increased with increasing parity (Table 3).

An apparent effect of season $(P<0.001)$ was present for IRCM in general (Table 3). On average, cows were more likely to experience clinical mastitis in late fall (December) than in the summer (Figure 7; Table 4). A small peak of IRCM appeared in the second half of July mainly in high BMSCC herds, which is the result of a peak in Staph. aureus and E. coli IRCM (Figures 7 and 8). The peak in the high BMSCC category was mainly caused by a peak in Staph. aureus and E. coli IRCM. A peak in $E$. coli IRCM was also noticed in the medium BMSCC category. For a mid-lactation, second-parity cow, IRCM was 6.3 cases per 10,000 cow-days at risk in June and 9.4 cases per 10,000 cow-days at risk in December. Effect of season was also clearly present for most pathogen-specific IRCM $(P<0.001)$, except for $C$. bovis IRCM ( $P=0.07$; Table 3$)$. Streptococcus uberis IRCM was highest in the summer (August), dependent on summer housing strategy for $E$. coli, and highest in December and January for other pathogens (Figures 8 and 9; Tables 3 and 4). Seasonal differences were largest for Strep. uberis, followed by Strep. dysgalactiae and smallest for $E$. coli in herds that kept cows inside only at night during the summer (Table 4).

All farms kept their cows inside during the winter months. During summer, lactating cows were kept inside day and night on 13 (4.5\%) farms. On 171 (57\%) farms, the cows were kept outside day and night, and on the remaining 116 (39\%) farms, the cows were kept inside at night only. The interaction of housing strategy with the season variables was only significant for $E$. coli IRCM. Cows that were confined in the summer were more likely to develop clinical $E$. coli mastitis in the summer than in the winter, and cows that were on pasture day and night during the summer had a higher E. coli IRCM in the winter (Tables 3 and 4). Streptococcus uberis IRCM was numerically lower in summer in totally confined herds and had no seasonal effect $(P=$ 0.14). For example, on August 1, for a mid-lactation, second-parity cow, Strep. uberis IRCM was 1.1 cases per 10,000 cow-days at risk on pasture and 0.3 cases per 10,000 cow-days at risk in a totally confined herd.

\section{DISCUSSION}

A pronounced association was found between season and the udder health parameters BMSCC, IRCM, pathogen-specific IRCM, and ICSCC corrected for stage of lactation. Predicted BMSCC and predicted "new" high ICSCC peaked in August to September, whereas 
Table 3. Final model estimates of coefficients and variances (Var) of general and pathogen-specific incidence rate of clinical mastitis on 274 Dutch dairy farms on the logit scale

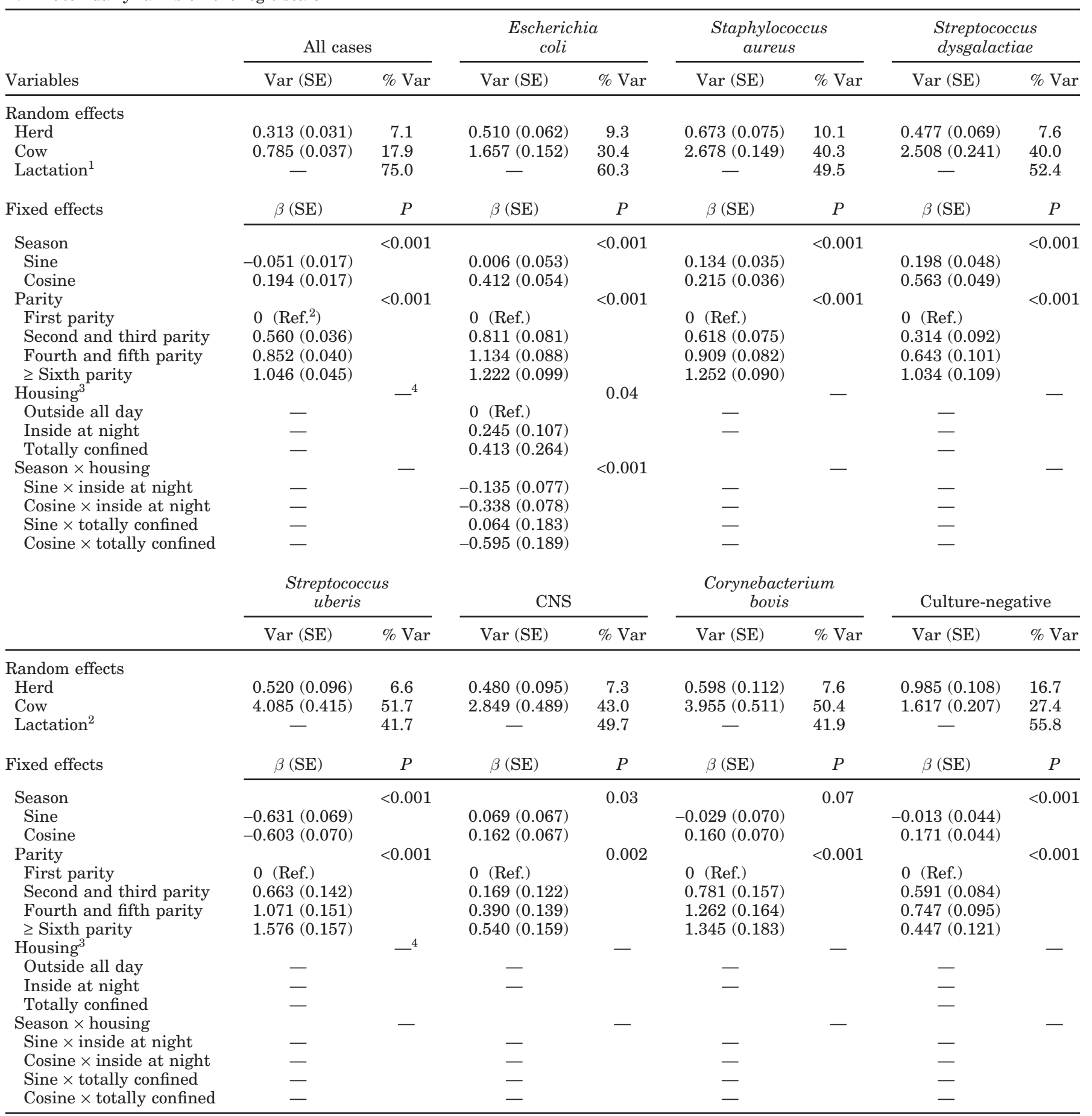

${ }^{1}$ Assumes level 1 variance on the logit scale is $\pi^{2} / 3$, where $\pi=3.1416 \ldots$ (Vigre et al., 2004).

${ }^{2}$ Ref. = reference category.

${ }^{3}$ Housing during summer; all cows were confined during winter.

${ }^{4}$ Nonsignificant effects $(P>0.05)$ were removed from the model. 


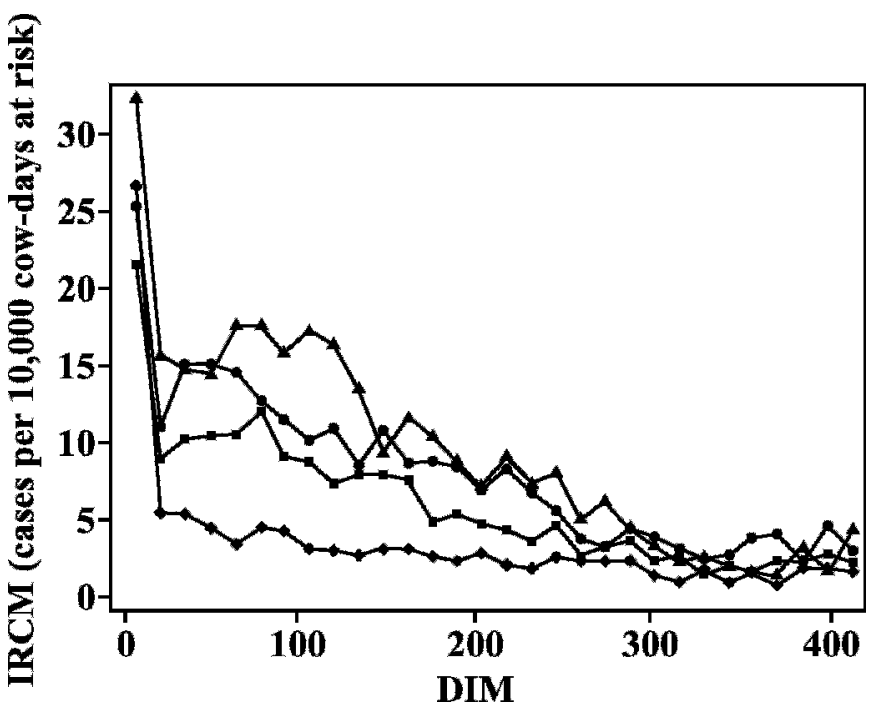

Figure 5. Distribution of incidence rate of clinical mastitis (IRCM) over lactation for heifers $(\checkmark)$, second and third parity ( $\mathbf{\square})$, fourth and fifth parity $(\bullet)$, and sixth and later parity cows $(\boldsymbol{\Lambda})$.

the peak for most pathogen-specific IRCM was in December or January. Streptococcus uberis IRCM, E. coli IRCM in semi-confined herds, and $E$. coli IRCM in totalconfined herds peaked in August, October, and June, respectively.

Calving was not evenly distributed over the year, and stage of lactation and parity are associated with ICSCC (Dohoo et al., 1984; Laevens et al., 1997; Green et al., 2004). Therefore, these variables were added to the models for IRCM and ICSCC. Not correcting for these

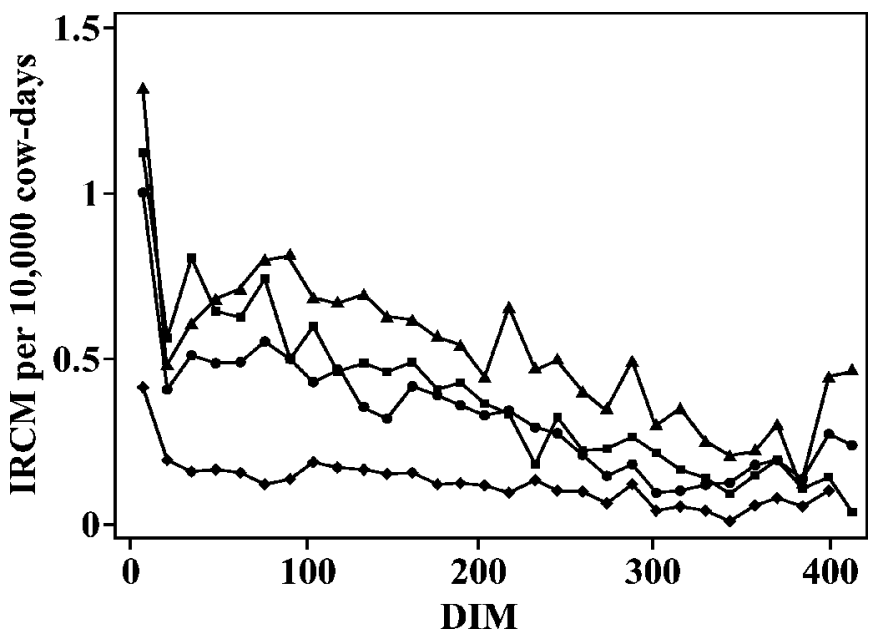

Figure 6. Predicted incidence rates of pathogen-specific clinical mastitis (IRCM) over lactation for heifers. Pathogens: Escherichia

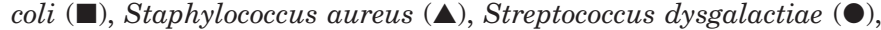
and Streptococcus uberis $(\bullet)$.

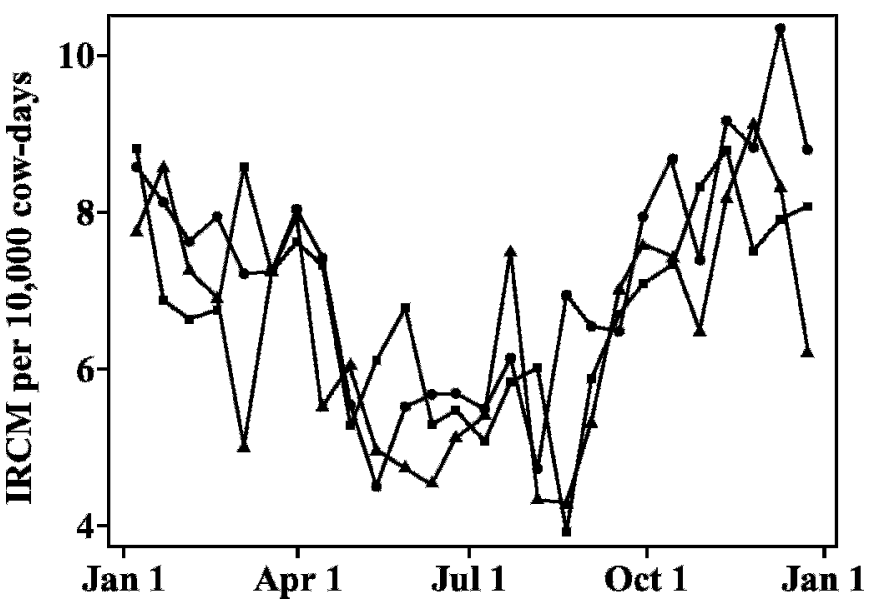

Figure 7. Incidence rate of clinical mastitis (IRCM) per 14-d period for herds with low ( $<150,000$ cells $/ \mathrm{mL}$; $)$, medium $(150,000-250,000$ cells/mL; - ), and high (250,000-400,000 cells/mL; $\mathbf{\Delta})$ bulk milk SCC.

variables would result in a bias in the effect of season on ICSCC and IRCM around the calving periods. Discrete time survival analyses for IRCM allowed calendar time to be modeled as a continuous predictor using a sine function, whereas biological time, or DIM, could be modeled in 14-d periods. A drawback of using 14-d periods is that some data were lost by excluding periods at risk that were shorter than $14 \mathrm{~d}$. Using shorter periods, however, would require more computer power than was available at the time of analysis. For the same reason, continuous time survival analyses for this data set would be less feasible if multilevel random effects and time varying covariates were to be added to the model.

The seasonal variation of BMSCC is in agreement with other studies that used a similar model to predict BMSCC (Sargeant et al., 1998a; Norman et al., 2000). In those studies, BMSCC peaked in late summer or fall as well. Because BMSCC is the product of the ICSCC and milk production included in the bulk tank, it is logical that the prevalence of high ICSCC follows the same pattern as that of the BMSCC. In a study conducted in 33 British dairy herds, Green et al. (2006) suggested that the increase in BMSCC in this period is the result of an increase in chronic high ICSCC. By contrast, in our study, the incidence of "new" elevated ICSCC was highest in August with a shorter lasting peak in April (Figure 3), and the peak in August coincided with the peak of the BMSCC (Figure 2), whereas the largest proportions of "chronic" high ICSCC were found in April (Figure 4). In Norway, prevalence of Staph. aureus and Strep. uberis IMI was highest in spring and summer, respectively (Østerås et al., 2006). Staphylococcus aureus and Strep. uberis IMI can cause clinical and subclinical mastitis with a prolonged period 
Table 4. Derived parameters from the final model estimates of coefficients and variances of general and pathogen-specific incidence rate of clinical mastitis on 274 Dutch dairy herds (Stolwijk et al., 1999; Weisberg, 2005) ${ }^{1}$

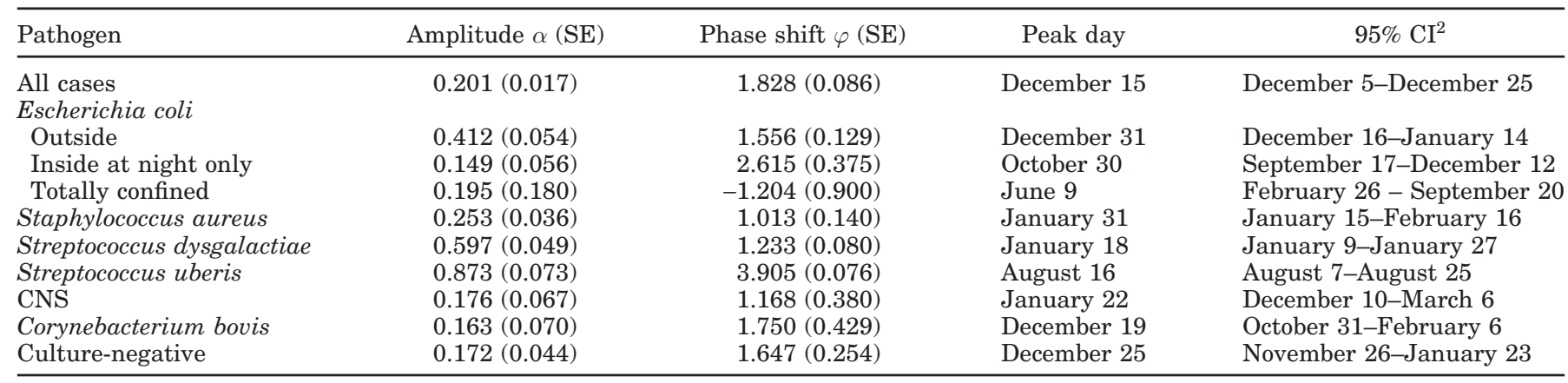

${ }^{1}$ Formulas are available on request from the authors.

${ }^{2} \mathrm{CI}=$ confidence interval.

of high ICSCC (De Haas et al., 2004). Therefore, a possible explanation for the predicted rise in probability of becoming a "chronic" or a "new" high ICSCC cow in April is an increased incidence of subclinical IMI caused by Staph. aureus, whereas the rise in "new" high ICSCC in August can be explained by an increased incidence of Strep. uberis IMI in that period. Another explanation could be that on farms that had difficulties producing the annual milk quota, high SCC cows that should be culled were kept longer on farm until May, the start of the new quota year.

Staphylococcus aureus, E. coli, and Strep. dysgalactiae IRCM peaked in December and January, whereas Strep. uberis IRCM was highest in August. Seasonal fluctuation of CNS and C. bovis IRCM were less pronounced. The peak in winter for most major pathogens was not in agreement with other studies (Smith et al., 1985; Erskine et al., 1988; Hogan et al., 1989b; Todhunter et al., 1991; Makovec and Ruegg, 2003) that reported a peak in summer for both coliforms and streptococci. These studies, however, were all performed in confined US herds. In our study, E. coli IRCM in totally confined herds was also higher in the summer compared with the pastured herds, which had the E. coli IRCM peak in winter, whereas $E$. coli IRCM was lower in summer in herds that kept their cows on pasture day and night (Barkema et al., 1999a). In totally confined herds, the summer heat and humidity of the cows' environment enhance the growth of $E$. coli in the environment, resulting in high coliform counts in bedding (Smith et al., 1985; Hogan et al., 1989b; Goldberg et al., 1992), and therefore a greater exposure to this pathogen.

The epidemiology of, particularly, Strep. uberis IMI and mastitis are not well understood. In this study, Strep. uberis IRCM peaked in summer. In Norway, prevalence of Strep. uberis IMI peaked in summer (Østerås et al., 2006). Streptococcus uberis IRCM was

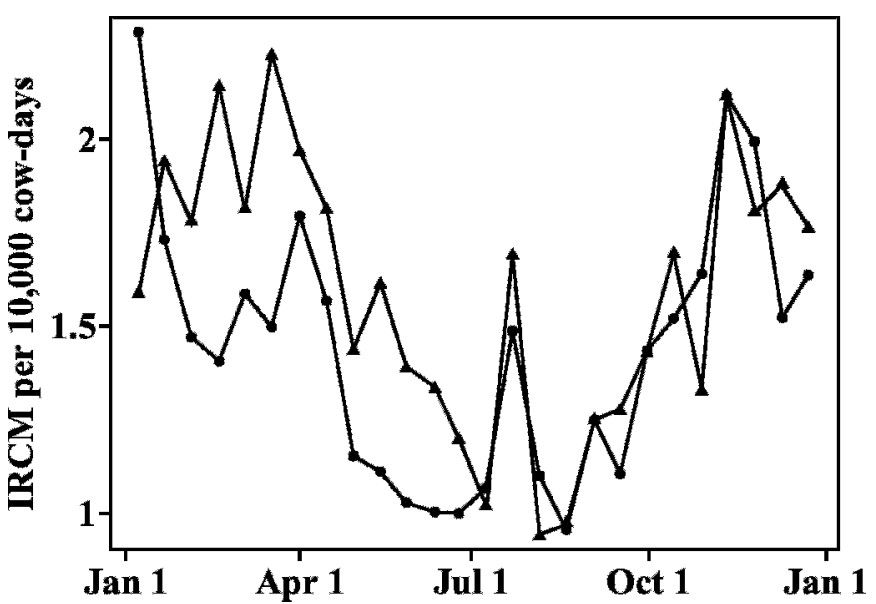

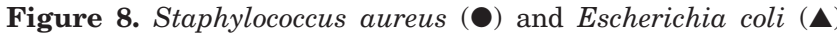
incidence rate of clinical mastitis (IRCM) per 14-d period.

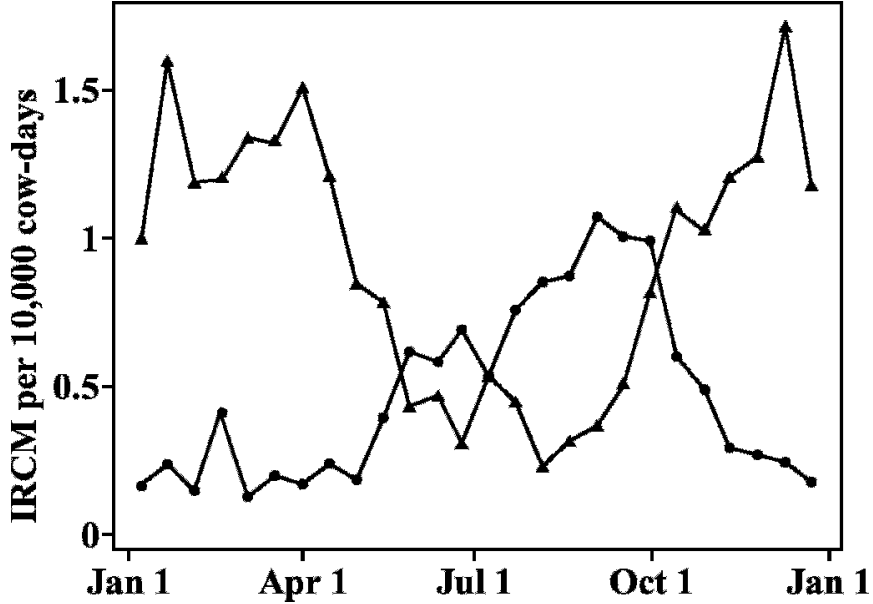

Figure 9. Streptococcus uberis (-) and Streptococcus dysgalactiae ( $\mathbf{\Delta})$ incidence rate of clinical mastitis (IRCM) per 14-d period. 
numerically lower in totally confined herds in summer than in herds that pastured the cows (results not shown). In a recent study by Zadoks et al. (2005), the proportion of fecal samples containing Strep. uberis was larger during the summer grazing season than during winter. In New Zealand, where cows are pastured all year, Strep. uberis is the most important mastitis pathogen, and clinical $E$. coli mastitis is relatively uncommon (Pankey et al., 1996; McDougall, 1998). Zadoks et al. (2005) could not find Strep. uberis in haylage, but found it in soil samples. This indicates that cows on pasture may maintain a contamination cycle through the feces. As a result, the infection pressure for Strep. uberis increases on pasture. A role of pasture contamination in the epidemiology of Strep. uberis has also been suggested by Cullen and Little (1969). In summary, evidence is mounting that Strep. uberis is a pasture-associated pathogen, at least in some geographic areas. Streptococcus uberis IRCM was high shortly after calving, but did not decline as much as for the other pathogens and was more or less constant throughout lactation (Figure 6). This indicates that, contrary to what was found in a confined US dairy herd for Strep. uberis IMI (Todhunter et al., 1995), clinical mastitis in Dutch dairy herds caused by Strep. uberis more often occurs during lactation, as was also found by Zadoks et al. (2003). Unlike for E. coli, immunosuppression during peak lactation does not seem to play an important role in the pathogenesis of Strep. uberis mastitis. Diet, however, could play a role in both $E$. coli and Strep. uberis IRCM. When lactating cows in the herd were fed corn silage, a lower overall IRCM and IRCM caused by Strep. uberis and a higher IRCM caused by $E$. coli were observed (Barkema et al., 1999a). Corn silage and haylage are more commonly fed in the winter when cows are kept inside.

A peak was noted in both $E$. coli and Staph. aureus IRCM in the second half of July in the high BMSCC category herds. These 2 pathogens have a different epidemiology and such a peak was not found for other pathogens. The number of cows at risk per day in the raw data in the summer period was approximately the same in this period as in others, whereas the absolute number of clinical mastitis cases per day was somewhat larger in July. A possible explanation of this peak could be a flare-up of existing Staph. aureus infections in the high BMSCC category herds and new $E$. coli infections in other herds (Figure 7). Although the Netherlands has a moderate climate, immunosuppression because of heat stress may also have played a role. The peak, however, did not have a large effect on the outcome of the E. coli and Staph. aureus IRCM models.

Herd-level variance for culture-negative samples was larger than for any of the pathogens studied. There are numerous reasons for a milk sample of a clinical mastitis case to be culture-negative. One possibility for this herd-level variation is that some herds had more Mycoplasma than did others. This seems unlikely, however, because prevalence of Mycoplasma mastitis is generally not high enough to explain most of the culturenegative samples, and the clinical appearance of the culture-negative mastitis cases did not indicate $\mathrm{Myco-}$ plasma mastitis. Milk samples in this study were not tested for Mycoplasma spp. because this would require special growth media. Culture-negative results are often attributed to either E. coli (Smith and Hogan, 1993) or Staph. aureus (Sears et al., 1990). Staphylococcus aureus IMI also frequently results in culture-negative milk samples, and certain strains more often result in culture-negative samples than others (Sears et al., 1990). Variation of culture-negative IRCM, however, was in our model not in accordance with herd-level variance of either Staph. aureus IRCM nor E. coli IRCM, and the effect of parity was different for culturenegative on one side and E. coli and Staph. aureus IRCM on the other side (Table 3). Therefore, samples can be culture-negative for a variety of reasons and might not be representative for one type of bacteria.

Coagulase-negative staphylococci IRCM, and to a lesser extent Strep. dysgalactiae IRCM, did not increase as much with parity as IRCM of other pathogens. Because Strep. dysgalactiae is mainly a contagious pathogen and has a more favorable response to antimicrobial treatment compared with Staph. aureus, prevalence of chronic Strep. dysgalactiae mastitis and therefore incidence of clinical flare-ups might be lower. Coagulasenegative staphylococci IRCM might be lower in later parities for a similar reason because they are a very diverse group of bacteria and some of them might not become chronically infected.

In many North American studies, the group of nonagalactiae streptococci was not differentiated (Oliver, 1998; Sargeant et al., 1998b; Makovec and Ruegg, 2003; Gröhn et al., 2004). The results of this study, however, indicate that the epidemiology of the 2 mastitis pathogens in this group that are isolated most frequently, Strep. dysgalactiae and Strep. uberis, is quite different. This is supported by other studies in terms of herdlevel risk factors (Barkema et al., 1999a), response to treatment (Swinkels et al., 2005) and contagiousness (Neave et al., 1969). Additionally, epidemiological characteristics even differ among strains within species (Zadoks et al., 2003). Therefore, besides Strep. agalactiae, at least Strep. dysgalactiae and Strep. uberis should be differentiated in research and also in routine bacteriological culture, whereas in research projects, strain typing needs to be considered. 


\section{CONCLUSIONS}

Season is associated with BMSCC, IRCM, pathogenspecific IRCM, and ICSCC. The increase of BMSCC in August and September cannot fully be explained by IRCM, but is most likely associated with the increase of cows with new high ICSCC and longer periods of high ICSCC. Distinguishing between Strep. uberis, Strep. dysgalactiae, Strep. agalactiae, and other streptococci is essential when identifying Streptococcus spp., because each of them has a unique epidemiology. Streptococcus uberis IRCM seems to be related to pasture, whereas other streptococci and E. coli seem to be more housingrelated. Thus, the present study demonstrates the importance of milk culture and differentiation of mastitis pathogens to be able to make specific recommendations in udder health control programs.

\section{REFERENCES}

Ali, A. K. A., and G. E. Shook. 1980. An optimum transformation for somatic cell concentration in milk. J. Dairy Sci. 63:487-490.

Barkema, H. W., Y. H. Schukken, T. J. G. M. Lam, M. L. Beiboer, G. Benedictus, and A. Brand. 1999a. Management practices associated with the incidence rate of clinical mastitis. J. Dairy Sci. 82:1643-1654.

Barkema, H. W., Y. H. Schukken, T. J. G. M. Lam, M. L. Beiboer, H. Wilmink, G. Benedictus, and A. Brand. 1998. Incidence of clinical mastitis in dairy herds grouped in three categories by bulk milk somatic cell counts. J. Dairy Sci. 81:411-419.

Barkema, H. W., J. D. Van der Ploeg, Y. H. Schukken, T. J. Lam, G. Benedictus, and A. Brand. 1999b. Management style and its association with bulk milk somatic cell count and incidence rate of clinical mastitis. J. Dairy Sci. 82:1655-1663.

Bodoh, G. H., W. J. Battista, L. H. Schultz, and R. P. Johnston. 1976. Variation in somatic cell counts in dairy herd improvement milk samples. J. Dairy Sci. 59:1119-1123.

Clements, A. C., D. U. Pfeiffer, and D. Hayes. 2005. Bayesian spatiotemporal modeling of national milk-recording data of seasonalcalving New Zealand dairy herds. Prev. Vet. Med. 71:183-196.

Cullen, G. A., and T. W. A. Little. 1969. Isolation of Streptococcus uberis from the rumen of cows and from soil. Vet. Rec. 85:115-118.

De Haas, Y., H. W. Barkema, Y. H. Schukken, and R. F. Veerkamp. 2005. Associations between somatic cell count patterns and the incidence of clinical mastitis. Prev. Vet. Med. 67:55-68.

De Haas, Y., R. F. Veerkamp, H. W. Barkema, Y. T. Gröhn, and Y. H. Schukken. 2004. Associations between pathogen-specific cases of clinical mastitis and somatic cell count patterns. J. Dairy Sci. 87:95-105.

Dohoo, I. R., A. H. Meek, and S. W. Martin. 1984. Somatic cell counts in bovine milk: Relationships to production and clinical episodes of mastitis. Can. J. Comp. Med. 48:130-135.

Erskine, R. J., R. J. Eberhart, L. J. Hutchinson, S. B. Spencer, and M. A. Campbell. 1988. Incidence and types of clinical mastitis in dairy herds with high and low somatic cell counts. J. Am. Vet. Med. Assoc. 192:761-765.

Faye, B., L. Perochon, N. Dorr, and P. Gasqui. 1998. Relationship between individual-cow udder health status in early lactation and dairy cow characteristics in Brittany, France. Vet. Res. 29:31-46.

Goldberg, J. J., E. E. Wildman, J. W. Pankey, J. R. Kunkel, D. B. Howard, and B. M. Murphy. 1992. The influence of intensively managed rotational grazing, traditional continuous grazing, and confinement housing on bulk tank milk quality and udder health. J. Dairy Sci. 75:96-104.

Green, M. J., A. J. Bradley, H. Newton, and W. J. Browne. 2006. Seasonal variation of bulk milk somatic cell counts in UK dairy herds: Investigations of the summer rise. Prev. Vet. Med. 74:293-308.

Green, M. J., L. E. Green, Y. H. Schukken, A. J. Bradley, E. J. Peeler, H. W. Barkema, Y. De Haas, V. J. Collis, and G. F. Medley. 2004. Somatic cell count distributions during lactation predict clinical mastitis. J. Dairy Sci. 87:1256-1264.

Gröhn, Y. T., D. J. Wilson, R. N. Gonzalez, J. A. Hertl, H. Schulte, G. Bennett, and Y. H. Schukken. 2004. Effect of pathogen-specific clinical mastitis on milk yield in dairy cows. J. Dairy Sci. 87:3358-3374.

Hogan, J. S., and K. L. Smith. 1997. Bacteria counts in sawdust bedding. J. Dairy Sci. 80:1600-1605.

Hogan, J. S., K. L. Smith, K. H. Hoblet, P. S. Schoenberger, D. A. Todhunter, W. D. Hueston, D. E. Pritchard, G. L. Bowman, L. E. Heider, and B. L. Brockett. 1989a. Field survey of clinical mastitis in low somatic cell count herds. J. Dairy Sci. 72:1547-1556.

Hogan, J. S., K. L. Smith, K. H. Hoblet, D. A. Todhunter, P. S. Schoenberger, W. D. Hueston, D. E. Pritchard, G. L. Bowman, L. E. Heider, and B. L. Brockett. 1989b. Bacterial counts in bedding materials used on nine commercial dairies. J. Dairy Sci. $72: 250-258$.

Laevens, H., H. Deluyker, Y. H. Schukken, L. De Meulemeester, R. Vandermeersch, E. De Muelenaere, and A. de Kruif. 1997. Influence of parity and stage of lactation on the somatic cell count in bacteriologically negative dairy cows. J. Dairy Sci. 80:32193226 .

Littell, R. C., G. A. Milliken, W. W. Stroup, and R. D. Wolfinger. 1996. SAS System for Mixed Models. SAS Inst. Inc., Cary, NC.

Makovec, J. A., and P. L. Ruegg. 2003. Results of milk samples submitted for microbiological examination in Wisconsin from 1994 to 2001. J. Dairy Sci. 86:3466-3472.

McDougall, S. 1998. Efficacy of two antibiotic treatments in curing clinical and subclinical mastitis in lactating dairy cows. N. Z. Vet. J. 46:226-232.

Morse, D., M. A. DeLorenzo, C. J. Wilcox, R. J. Collier, R. P. Natzke, and D. R. Bray. 1988. Climatic effects on occurrence of clinical mastitis. J. Dairy Sci. 71:848-853.

Neave, F. K., F. H. Dodd, R. G. Kingwill, and D. R. Westgarth. 1969. Control of mastitis in the dairy herd by hygiene and management. J. Dairy Sci. 52:696-707.

Norman, H. D., R. H. Miller, J. R. Wright, and G. R. Wiggans. 2000. Herd and state means for somatic cell count from dairy herd improvement. J. Dairy Sci. 83:2782-2788.

Oliver, S. P. 1998. Frequency of isolation of environmental mastitiscausing pathogens and incidence of new intramammary infections during the non-lactating period. Am. J. Vet. Res. 49:1789-1793.

Østerås, O., L. Sølverød, and O. Reksen. 2006. Milk culture results in a large Norwegian survey-Effects of season, parity, days in milk, resistance and clustering. J. Dairy Sci. 89:1010-1023.

Pankey, J. W., P. B. Pankey, R. M. Barker, J. H. Williamson, and M. W. Woolford. 1996. The prevalence of mastitis in primiparous heifers in eleven Waikato dairy herds. N. Z. Vet. J. 44:41-44.

Rasbash, J. W., H. Browne, M. Goldstein, M. Yang, I. Plewis, M. Healy, G. Woodhouse, D. Draper, I. Langford, and T. Lewis. 2000. A user's guide to MLwiN. Version 2.1. Institute of Education, London, UK.

Salsberg, E., A. H. Meek, and S. W. Martin. 1984. Somatic cell counts: Associated factors and relationship to production. Can. J. Comp. Med. 48:251-257.

Sargeant, J. M., Y. H. Schukken, and K. E. Leslie. 1998a. Ontario bulk milk somatic cell count reduction program: Progress and outlook. J. Dairy Sci. 81:1545-1554.

Sargeant, J. M., H. M. Scott, K. E. Leslie, M. J. Ireland, and A. Bashiri. 1998b. Clinical mastitis in dairy cattle in Ontario: Frequency of occurrence and bacteriological isolates. Can. Vet. J. 39:33-38.

Schukken, Y. H., Y. T. Gröhn, B. McDermott, and J. J. McDermott. 2003. Analysis of correlated discrete observations: Background, examples and solutions. Prev. Vet. Med. 59:223-240.

Schukken, Y. H., K. E. Leslie, A. J. Weersink, and S. W. Martin. 1992. Ontario bulk milk somatic cell count reduction program. 1. Impact on somatic cell counts and milk quality. J. Dairy Sci. 75:3352-3358. 
Schukken, Y. H., A. Weersink, K. E. Leslie, and S. W. Martin. 1993. Dynamics and regulation of bulk milk somatic cell counts. Can. J. Vet. Res. 57:131-135.

Sears, P. M., B. S. Smith, P. B. English, P. S. Herer, and R. N. Gonzalez. 1990. Shedding pattern of Staphylococcus aureus from bovine intramammary infections. J. Dairy Sci. 73:2785-2790.

Simensen, E. 1976. Milk somatic cells in dairy cows kept on pasture or confined indoors during the summer. Nord. Vet. Med. 28:603-609.

Singer, J. D., and J. B. Willett. 1993. It's about time: Using discretetime survival analysis to study duration and the timing of events. J. Educ. Stat. 18:155-195.

Singer, J. D., and J. B. Willett. 2003. Applied Longitudinal Data Analysis. Modeling Change and Event Occurrence. Oxford University Press, Oxford, UK.

Smith, K. L., and J. S. Hogan. 1993. Environmental mastitis. Vet. Clin. North Am. Food Anim. Pract. 9:489-498.

Smith, K. L., D. A. Todhunter, and P. S. Schoenberger. 1985. Environmental mastitis: Cause, prevalence, prevention. J. Dairy Sci. 68:1531-1553

Stolwijk, A. M., H. Straatman, and G. A. Zielhuis. 1999. Studying seasonality by using sine and cosine functions in regression analysis. J. Epidemiol. Community Health 53:235-238.

Swinkels, J. M., J. G. A. Rooijendijk, R. N. Zadoks, and H. Hogeveen. 2005. Use of partial budgeting to determine the economic benefits of antibiotic treatment of chronic subclinical mastitis caused by
Streptococcus uberis or Streptococcus dysgalactiae. J. Dairy Res. 72:75-85.

Todhunter, D. A., K. L. Smith, and J. S. Hogan. 1995. Environmental streptococcal intramammary infections of the bovine mammary gland. J. Dairy Sci. 78:2366-2374.

Todhunter, D. A., K. L. Smith, J. S. Hogan, and P. S. Schoenberger. 1991. Gram-negative bacterial infections of the mammary gland in cows. Am. J. Vet. Res. 52:184-188.

Vigre, H., I. R. Dohoo, H. Stryhn, and M. E. Busch. 2004. Intra-unit correlations in seroconversion to Actinobacillus pleuropneumoniae and Mycoplasma hyopneumoniae at different levels in Danish multi-site pig production facilities. Prev. Vet. Med. 63:9-28.

Weisberg, S. 2005. Using the delta method to estimate a minimum or a maximum. Pages 120-122 in Applied Linear Regression. 3rd ed. Wiley Series in Probability and Statistics. Wiley-Interscience, New York, NY.

Whitaker, D. A., A. I. Macrae, and E. Burrough. 2004. Disposal and disease rates in British dairy herds between April 1998 and March 2002. Vet. Rec. 155:43-47.

Zadoks, R. N., B. E. Gillespie, H. W. Barkema, O. C. Sampimon, S. P. Oliver, and Y. H. Schukken. 2003. Clinical, epidemiological and molecular characteristics of Streptococcus uberis infections in dairy herds. Epidemiol. Infect. 130:335-349.

Zadoks, R. N., L. L. Tikofsky, and K. J. Boor. 2005. Ribotyping of Streptococcus uberis from a dairy's environment, bovine feces and milk. Vet. Microbiol. 109:257-265. 